\title{
Increasing Energy Efficiency and Modernization of Energy Systems in Russia: A Review
}

\author{
Wadim Strielkowski ${ }^{1,2, *(\mathbb{D}, \text { Anna Sherstobitova }}{ }^{3}$, Patrik Rovny ${ }^{4}$ and Tatiana Evteeva ${ }^{4}$ \\ 1 Department of Agricultural and Resource Economics, University of California, Berkeley, 303 Giannini Hall, \\ Berkeley, CA 94720, USA \\ 2 Department of Trade and Finance, Faculty of Economics and Management, Czech University of Life Sciences \\ Prague, Kamýcká 129, Prague 6, 16500 Prague, Czech Republic \\ 3 Department of Master's Degree (Business Programs), Institute Finance, Economics and Management, \\ Togliatti State University, Belorusskaya Str. 14, 445020 Togliatti, Russia; a.sherstobitova@tltsu.ru \\ 4 Department of Marketing and Trade, Faculty of Economics and Management, Slovak University of \\ Agriculture in Nitra, Tr. A. Hlinku 2, 94976 Nitra, Slovakia; rovny@uniag.sk (P.R.); \\ xevteeva@is.uniag.sk (T.E.) \\ * Correspondence: strielkowski@berkeley.edu
}

Citation: Strielkowski, W.;

Sherstobitova, A.; Rovny, P.; Evteeva, T. Increasing Energy Efficiency and Modernization of Energy Systems in Russia: A Review. Energies 2021, 14, 3164. https://doi.org/10.3390/ en14113164

Academic Editors: Andrea Mariscotti and Angelo Zarrella

Received: 8 April 2021

Accepted: 26 May 2021

Published: 28 May 2021

Publisher's Note: MDPI stays neutral with regard to jurisdictional claims in published maps and institutional affiliations.

Copyright: (c) 2021 by the authors. Licensee MDPI, Basel, Switzerland. This article is an open access article distributed under the terms and conditions of the Creative Commons Attribution (CC BY) license (https:// creativecommons.org/licenses/by/ $4.0 /)$.

\begin{abstract}
The main purpose of this research is to assess the energy efficiency in Russia on its path towards the modernization of its energy systems. This modernization can be seen as an effective means for promoting decarbonization and energy-saving initiatives. Our methods include a comprehensive overview of the development of the energy sector in Russia, which is distinguished by the high concentration of state-owned enterprises, the absence of clear market mechanisms, as well as the domination of the fossil fuels represented by natural gas and oil. Furthermore, we present the perspectives of developing the renewable energy technologies in Russia. Our results enable us to create an in-depth analysis of the perspectives of modernization of the Russian energy sector and to draw the key connotations for its further development. Moreover, the outcomes of this paper can provide useful policy implications and guidelines for modernizing energy efficiency and energy systems for Russian stakeholders and policy makers, supporting their efforts to reduce the dependency on carbon fuels and to embark on the path towards the sustainable economic growth and development.
\end{abstract}

Keywords: energy efficiency; decarbonization; energy consumption; modernization; Russian Federation

\section{Introduction}

Tools such as the maximization of energy efficiency, modernization of power distribution electrical systems (i.e., decentralization, distributed generation or deployment of renewable energy) as well as the shift towards the carbon-free economy all constitute powerful means for tackling global warming and climate change. All of them are gradually becoming the priority of governments and nations worldwide [1]. For example, in the European Union (EU), the European Energy Efficiency Directive (EED) aims at reducing energy consumption by $20 \%$ by 2025 together with creating 400,000 new jobs [2,3]. EU already set up the ambitious targets for 2030 aiming at the reduction of $40 \%$ of greenhouse gas emissions (as compared to the 1990), as well as increasing the share of renewable energy in the total gross energy production to $27 \%$ [4].

\subsection{Modernization and Energy Efficiency for Business Strategies and Competitiveness}

All over the world, stakeholders and policy makers are intensifying the new energy efficiency measures, including the increase in the energy efficiency of the buildings, creation of the transparency in energy consumption via more accurate measurements utilizing smart meters, as well as application of the novel smarter energy demand management 
techniques [5,6]. Tackling these issues can help them to gain a better understanding of the challenges they face in building successful and efficient energy sector. It was estimated that an investment in the energy efficiency of EUR 24 billion into the EU energy sector could reduce energy costs by EUR 6 billion per year in accordance with the European Energy Efficiency Directive [7]. With the renewable energy sources such as wind, solar, geothermal, and hydropower becoming more energy-efficient, this decision could push energy companies to turn away from the fossil fuels [8,9]. Furthermore, energy professionals can help with what is known as energy procurement, which involves optimal energy sources for business companies. They can provide reliable and relevant information, so these companies can explore green energy options while working towards energy efficiency targets $[10,11]$.

Nowadays, the majority of policy makers and energy stakeholders recognize the fact that if they want to make meaningful progress on energy efficiency, they must create targets that are both feasible and challenging. The focus on sustainability and energy efficiency can provide the countries with a unique competitive advantage, especially in the small business sector. Energy prices are likely to rise in the coming years, and a sustainable and environmentally conscious approach can help small business branding [12]. Some companies are even said to have increased their energy efficiency by $30 \%$ through the recent modernization in the energy sector [13].

Another important aspect of energy efficiency is aligning business strategies of companies with their environmental concerns. Sustainable and environmentally conscious businesses can become a key factor in the ability of these companies to set up their priorities with a view of the sustainable development [14,15]. By learning about the benefits of energy efficiency, business companies can help the environment, and making the investment in their companies' sustainable futures is a good contribution that can provide many positive outcomes [16]. One of the common myths about energy efficiency of business companies is that only large companies and corporations can afford to "go green" and to be energy-efficient. In spite of this myth, a significant amount of work should be carried out by all types of business companies regardless of their countries of operation to make the business sector more energy efficient-both in terms of energy consumption and energy efficiency [17].

In addition, the recent shift towards sustainable economic growth makes business managers focus on overcoming cost and efficiency barriers. This might help to avoid unnecessary waste of energy, reduce the environmental footprint and help the environment by investing in the energy efficiency measures and integrating energy savings into the daily business routine $[18,19]$. The advanced technical solutions that provide a fast and easy process to encourage investment into energy efficiency and risk management might also help business companies to become more environmentally friendly in all of their activities by making energy efficiency and risk management a part of their business plans [20]. Fortunately, energy efficiency of the business enterprises is often easy to achieve and there is a lot of help that can be offered by the modern technologies that are a part of the smart grid and the co-called "Internet of Energy" (IoE). Some efficiency improvements are very cost-effective and easy to implement, while more expensive conversions can be financed by generating positive net cash flow when energy costs surpass the revenues [21]. With the recent development of information and communication technologies (ICTs), renewable energy and green pricing schemes can more easily support efficient business enterprises. Energy utilities worldwide introduce efficiency programs aimed at working with business customers for reduction in energy costs and saving money. Companies can save by planning their electricity consumption for economic downturns and reduce the amount of efficiency when needed. Business customers not only recognize that they are more energy-efficient, but also draw from the environmental benefits. A cleaner and greener approach to energy use can also benefit the community [22] and therefore should be introduced even in those countries where fossil fuels are the main priority and a major source of income (which is exactly the case of the Russian Federation). 


\subsection{Prospects for Modernization of Russian Energy Sector}

Today, as the Russian Federation is setting upon the path of modernization of its power distribution electrical systems through decarbonization, energy saving and the introduction of renewable energy sources, energy efficiency becomes an important and studied topic. Russia is making attempts to transform its energy sector by using modern technologies, novel management methods and environmentally friendly approaches. Even though the share of the renewable energy in this country still remains very low, the recent trends and efforts represent an interesting research topic and constitute a considerable scientific added value.

The main objective of this work is to show how the energy efficiency can be increased and the electrical energy systems can be modernized in Russia. This is carried out using a thorough review of the available research literature and policy documents. In addition, the novelty of this work is in embedding the analysis of the potential for the renewable energy sources in Russia within the context of the objectives described above. To the best of our knowledge, there are very few reviews tackling both issues at once with a focus on the Russian energy systems.

This paper is organized as follows. Section 2 provides an overview of the recent developments and future prospects of the energy sector in the Russian Federation focusing on its main shortcomings. Section 3 assesses the issues of energy efficiency and energy management in Russia. Section 4 tackles the energy saving and modernization of power distribution electrical systems in Russia and offers some effective solutions that might be applied for achieving these goals. Finally, Section 5 concludes with the summary of concrete outcomes, relevant policy implications as well as pathways for further research in this area.

\section{Energy Sector in Russia: Recent Development and Future Prospects}

The Russian energy sector represents an interesting object of study by all available accounts. It is distinguished by the highly centralized nature and dense corporate concentration that quite often defy the usual market processes [23,24]. The Russian energy sector was created in the times of the Soviet Union when the concentration of industry was a part of national 5-year plans for the development of the social economy and centralization was ubiquitous $[25,26]$. As a result, the modern Russian energy sector faces many obstacles that include all obsolete infrastructures, energy agglomerates that feature large factories supplying heat and electricity to their satellite cities, as well as inefficient approaches to energy management [27-29]. On the other hand, the Russian energy sector today can boast a plethora of energy-generating facilities, high quality of energy specialists and personnel as well as extensive energy transmission networks [30]. Hence, a transition of the country's energy sector to a higher and a qualitatively new level due to the structural transformation of the electric power industry is required. In our study, we argue that it can be achieved by implementing several important steps including:

- An increase in the share of distributed generation in the total energy production;

- An increase in the share of consumption of higher-quality and more environmentally friendly energy throughout the cycle of energy production.

Quite a considerable part of Russian territory (especially the European part of the country) is energy-deficient from the point of view of own electricity supply [31-33]. At the same time, the level of gasification of the Russian regions is sufficiently high. There exist prerequisites for the creation of cogeneration plants of small (from 1 to $50 \mathrm{MW}$ ) and medium (from 50 to $150 \mathrm{MW}$ ) power, gas-fired, in energy-deficient regions. This allows their own electric power shortage to be compensated for and an increase in the proportion produced on the heat consumption, thereby providing fuel savings in the production process [34,35]. 


\subsection{Brief Overview of the Russian Energy Sector}

For more than 150 years, coal was the dominant fuel of the Russian industry and many key industrial centers were located near coal deposits [36-38]. As the rich reserves of fuel became available in the 1960s and 1970s, oil and natural gas surpassed coal as the primary energy source when coal ran out. Russia's coal reserves are estimated at about 1.5 billion tons, an amount that is greater than current utilization trends [39]. About three-quarters of Russia's coal is produced in Siberia and the Far East, with most of Europe's contributions coming from the United States and Europe, as well as other parts of the world, such as the Middle East [40,41].

Russia's economy is largely dependent on energy exports with the oil accounting for 35\% [42-44]. In 2006, the oil and gas industry contributed more than half of Russia's USD 1.5 trillion gross domestic product (GDP), making it the world's second-largest oil exporter after the United States [45]. The Russian energy sector plays an important role in Russia's economy by stimulating economic growth through revenues and exports, providing consumers with access to energy at acceptable prices and meeting the needs of related sectors [46-48]. In 2012, Russia's total export revenues from the energy sector amounted to about half of the federal budget and accounted for about one-third of its total gross domestic product (GDP), which made it a candidate for the "Dutch disease" (some researchers even came up with the special term "Russian disease"). Let us explain the last point: in the case of the "Dutch disease", the boom in raw materials (energy sources), leads to an increase in the real exchange rate and a loss of competitiveness in manufacturing industries that experience de-industrialization under the combined effects of rising wage costs, foreign competition, and declining investment. The Russian case only partly followed the predictions of the Dutch disease model, so the institutional dimension of the influence of the oil rent in Russia can be better called the "Russian disease" (see Grouiez et al. [49]). Moreover, by 2020, Russia's actual electricity consumption was $2.5 \%$ of its gross domestic product [50]. Figure 1 shows the total energy supply in the Russian Federation by source for the last 18 years (it has to be noted that the $Y$-axis of Figure 1 and all the other relevant figures that follow displays ktoe as units since this are the units reported by many international organizations including, for example, the International Energy Agency). It can be observed that while the share of the traditional energy sources such as oil, coal and natural gas occupies a considerable share in the Russian energy balance, the share of renewables (as well as nuclear) is increasing very slowly.

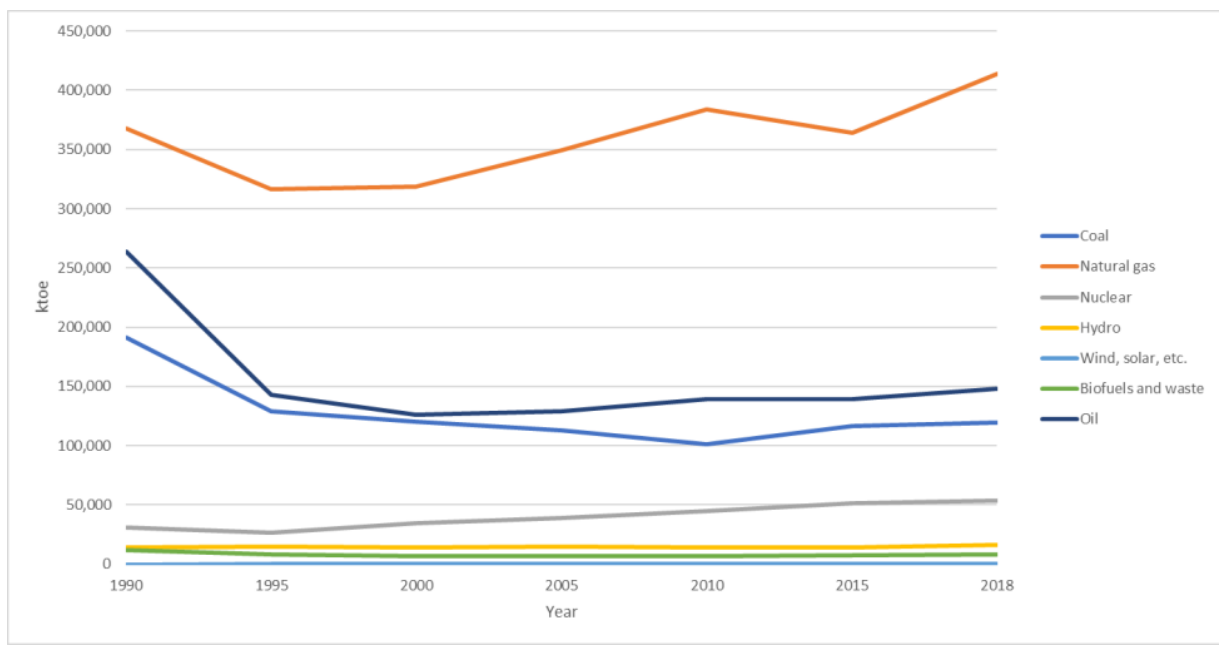

Figure 1. Total energy supply in the Russian Federation by source (1990-2018). Source: Own results based on [51].

For the sake of clarity, we would like to provide the following table (see Table 1) that lists the total energy supply and the main energy sources in Russia by years. 
Table 1. Energy supply in Russia by source (in ktoe).

\begin{tabular}{ccccccccc}
\hline & $\mathbf{1 9 9 0}$ & $\mathbf{1 9 9 5}$ & $\mathbf{2 0 0 0}$ & $\mathbf{2 0 0 5}$ & $\mathbf{2 0 1 0}$ & $\mathbf{2 0 1 5}$ & $\mathbf{2 0 1 8}$ \\
\hline Coal & 191,114 & 129,203 & 119,991 & 112,582 & 101,439 & 116,481 & 119,587 \\
\hline Natural gas & 367,391 & 316,635 & 319,007 & 349,669 & 383,544 & 364,253 & 413,707 \\
\hline Nuclear & 31,294 & 26,244 & 34,413 & 39,248 & 44,753 & 51,270 & 53,637 \\
\hline Hydro & 14,266 & 15,083 & 14,108 & 14,848 & 14,315 & 14,445 & 16,435 \\
\hline Wind and solar & 24 & 26 & 50 & 353 & 430 & 157 & 185 \\
\hline Biofuels and waste & 12,182 & 8537 & 6898 & 6916 & 6944 & 7663 & 139,365 \\
\hline Oil & 263,778 & 142,718 & 126,112 & 129,198 & 139,080 & 148,281 \\
\hline \multicolumn{2}{c}{ Source: own results based on $[51]}$. & &
\end{tabular}

Russia is also the second largest producer of hydropower in the world after the United States, with a total capacity of $47 \mathrm{GW}$, and is the third largest producer in terms of total electricity generation, accounting for more than $80 \%$ of the country's total electricity generation capacity, surpassed only by China and the United States [52,53]. Russia supplies more than half of its total energy needs to its closest neighbors [54]. Exports of Russian fuel and energy products by types are listed in Table 2 below.

Table 2. Exports of Russian fuel and energy products in USD billion (2015-2019).

\begin{tabular}{cccccc}
\hline & $\mathbf{2 0 1 5}$ & $\mathbf{2 0 1 6}$ & $\mathbf{2 0 1 7}$ & $\mathbf{2 0 1 8}$ & $\mathbf{2 0 1 9}$ \\
\hline Crude oil & 89.6 & $\mathbf{7 3 . 7}$ & 93.4 & 129.2 & 121.4 \\
\hline Petroleum products & 67.5 & 46.1 & 58.2 & 78.2 & 66.9 \\
\hline Gas (including LNG) & 46.4 & 34.2 & 41.9 & 54.4 & 49.6 \\
\hline Others & 12.7 & 12.2 & 18.5 & 25.2 & 24.6 \\
\hline
\end{tabular}

Source: own results based on [55].

The main recipient country for electricity is Finland, which accounts for about $2.5 \%$ of Russia's electricity consumption, or about 1.4 billion $\mathrm{kWh}$ [56]. In addition, Russia ranks third as the net exporter of coal. As of 2019, it is also the largest producer of natural gas with 679 billion cubic meters $[57,58]$. Table 3 shows the patterns of energy consumption in Russia.

Table 3. Energy consumption (million toe) and energy intensity (toe/thousand rubles) in the Russian Federation.

\begin{tabular}{cccccc}
\hline & $\mathbf{2 0 1 5}$ & $\mathbf{2 0 1 6}$ & $\mathbf{2 0 1 7}$ & $\mathbf{2 0 1 8}$ & $\mathbf{2 0 1 9}$ \\
\hline $\begin{array}{c}\text { Energy consumption, } \\
\text { million toe }\end{array}$ & 940.7 & 950.2 & 953.1 & 985.1 & 962.3 \\
\hline $\begin{array}{c}\text { Energy intensity, } \\
\text { toe/thousand rubles }\end{array}$ & 0.0114 & 0.01147 & 0.0108 & 0.0107 & 0.00473 \\
\hline $\begin{array}{l}\text { Source: Own results based on [59]. } \\
\text { nat }\end{array}$
\end{tabular}

Even though oil and natural gas are haphazardly used in all spheres of Russian economy, the country also exports them abroad (with those exports representing $30 \%$ of Russia's energy production). Nevertheless, if Russia wants to become a developed market economy, this dependency on carbon fuels needs to be diminished.

One of the major problems with the management of the energy sector in Russia is the vast size of the country, which makes the logistics very complicated. Some parts of the Russian Federation have limited links with neighboring countries, which reduces the ability of new companies to enter energy supply markets by importing energy from 
the neighboring energy systems. Hence, distributed generation and distributed energy resources become the best option in this situation [60,61]. All of the above strengthens the importance of transformation towards renewable energy.

\subsection{Approaches to the Energy Management: The Case of Russia}

Looking back at the history of the Russian energy sector, one of the most significant phases that determined the development of a systemic approach to energy management in the Soviet Union that can be pointed out is the energy crisis of the 1970s, which was triggered by the collapse of Russia's oil and gas industry and the subsequent collapse of oil prices $[62,63]$. The energy crisis negatively impacted the ability of Soviet export channels to tap into local energy resources. This was often linked to the decline of the energy efficiency and its impact on energy supply and demand, which became particularly acute during the economic crisis.

One of the crucial consequences of the Soviet energy crisis of the 1970s was that energy-saving technologies remained the key component in the development of energy management and efficiency in post-Soviet Russia [64]. This is linked to the modern phase of social and economic development in the country, characterized by decentralized planning and the emphasis on the use of renewable energy sources such as wind, solar and hydro. The peculiarity of the development of Russian energy infrastructure also determined its investment policy. The rules for the wholesale electricity market were adopted by decree of the Russian Government (No. 1172 of 27 December 2010, “On Wholesale Market Rules"). Russia's accession to the WTO was preceded by a series of federal legislative acts, which are reflected in the legislation of the Russian Federation (e.g., "Energy and Energy Management Act"). Wholesale electricity rules adopted by the Russian Government Regulation aimed at reducing the energy intensity of Russia's GDP to $13.5 \%$ by 2020 from the current $16.7 \%$ [65]. However, for the majority of Russian business enterprises, the introduction of the energy management systems is likely to be driven by a desire to increase energy efficiency at the expense of such an implementation [66].

Russia's approach to energy management is quite different from that used internationally. Some researchers speak of the politicized myth of energy waste in the economy which is often ignored [67]. For example, it has been calculated that Russia wastes an amount of energy that would be sufficient to power France or Britain for a whole year, and that the potential energy saving could be as much (some estimates state that would be about $40 \%$ of GDP) by 2020 [68]. This fact gains particular importance in the light of the Russian government's plan to increase its energy exports as far as energy saving might create additional energy resources. As a result, the Russian government introduced a law that aims at increasing the energy efficiency in 2020 by $40 \%$ of GDP. It is therefore clear that the existing mechanisms for managing energy savings and energy efficiency do not fully exploit the potential of innovative activities for achieving strategic results $[69,70]$.

Major energy companies in Russia, the state-owned Gazprom (specializing in natural gas) and Rosnfet (specializing in oil), are expected to improve energy efficiency, thereby reducing costs and environmental impacts [71,72]. To this end, Gazprom developed and implemented a series of energy efficiency and management strategies. For example, in 2018, the Management Committee of Gazprom approved the implementation of the Energy Efficiency and Energy Management Plan for 2018-2020. This was carried out in coordination with the Russian Academy of Sciences and the Ministry of Energy and Natural Resources [73]. The main objective was to support the implementation of energy management systems in accordance with the international standards. Within this framework, other Russian energy companies received the support from the Russian government in the implementation of an advanced energy management systems, the development of energy efficiency strategies to manage their energy consumption and the burgeoning and acquisition of funds aimed at the implementation of energy-saving programs. All these top-to-bottom initiatives fostered the development and optimization of the industrial 
systems and the implementation of energy management systems in the Russian energy companies [74].

\subsection{Energy Intensity and RES in Russia}

Extrapolations can be made for the dynamics of energy intensity of Russia's GDP using current trends and development (see Figure 2). In general, three scenarios can be drawn. The scenarios are based on the methodology developed by the Ministry of Economic Development of Russia in its report from 2019 on the on the state of energy conservation and energy efficiency in the Russian Federation, which outlines the values of the indices mapping possible scenarios for further development [75]. In order to do so, we employed the regression analysis method based on the single-factor linear regression model used for calculating the energy intensity of the Russian GDP. The coefficient of elasticity $\left(K_{e}\right)$ can be expressed by the formula presented in Equation (1):

$$
K_{e}=b *(\bar{x} / \bar{y})
$$

where: $b$-constant of the independent variable of the regression model showing the effect of the indicator; $x$-average value of the independent variable for the given period; $y$-average value of the dependent variable for the given period.

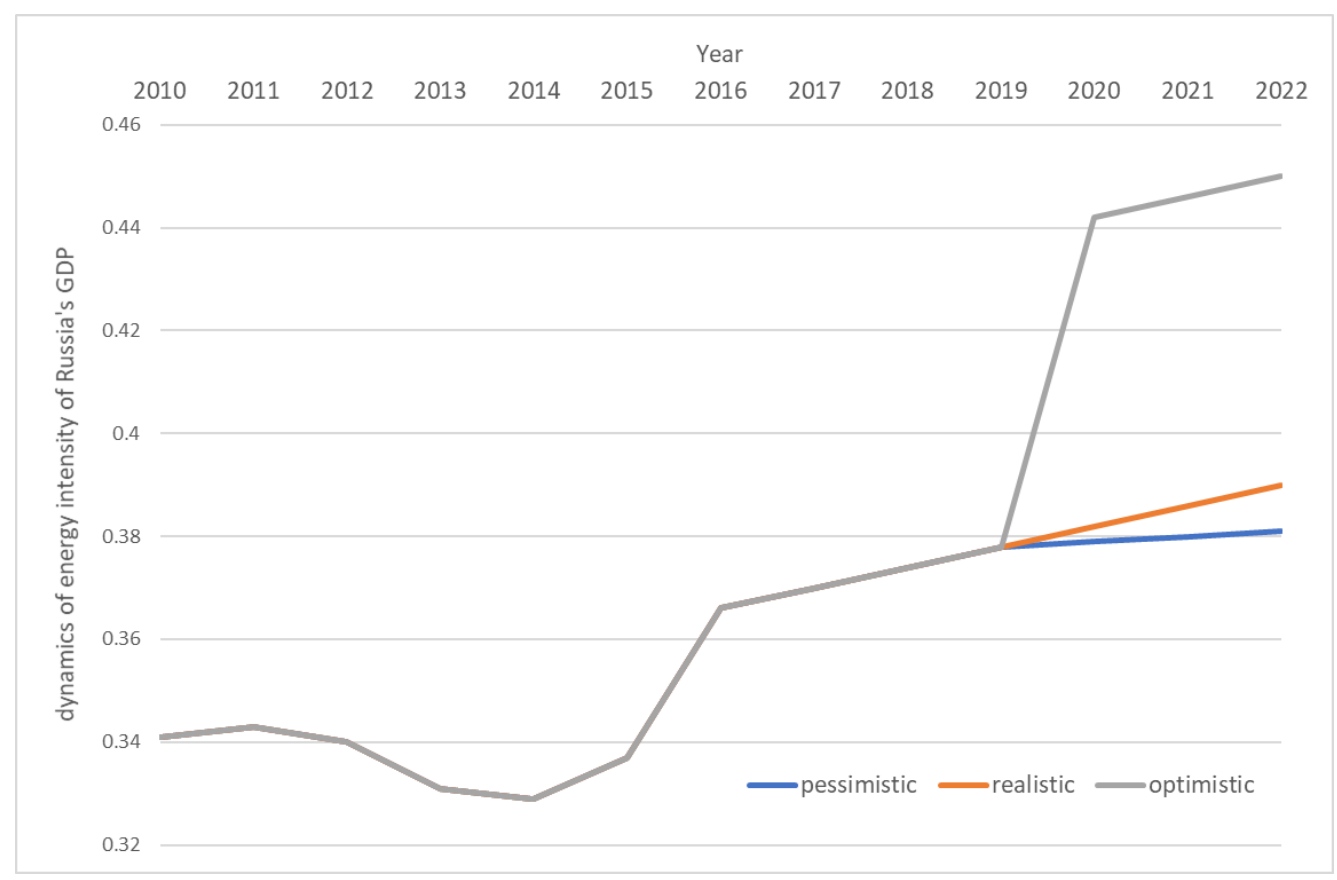

Figure 2. Dynamics of energy intensity of Russia's GDP. Source: own results.

As soon as the Russian production reaches the levels that would be comparable with the Western economies, its energy sector is likely to remain centralized [76]. The Soviet system artificially priced energy far below the level of world market prices. Soviet energy pricing policies prevented the introduction of austerity measures and disregarded resource use in the search for higher production volumes. All of those issues were inherited by Russia. As a result, Russia introduced a price of more than USD 1000 per kilowatt hour $(\mathrm{kWh})$ of energy, which is far above the global average. This effectively stopped the influx of foreign developers of renewable energy and created a new incentive for the domestic renewable energy market $[77,78]$.

As for the renewable energy sources in Russia, it would be useful to demonstrate some figures and numbers. Figure 3 above sheds some light on the development of renewable energy sources in Russia. The figure reveals the rise in hydro power as well as biofuel, wind and solar power. In addition, a trend in wind and solar power is marked with a 
dotted line. In spite of the clear trend in the rise in wind and solar, their share still remains marginal in comparison to as hydro power or nuclear power.

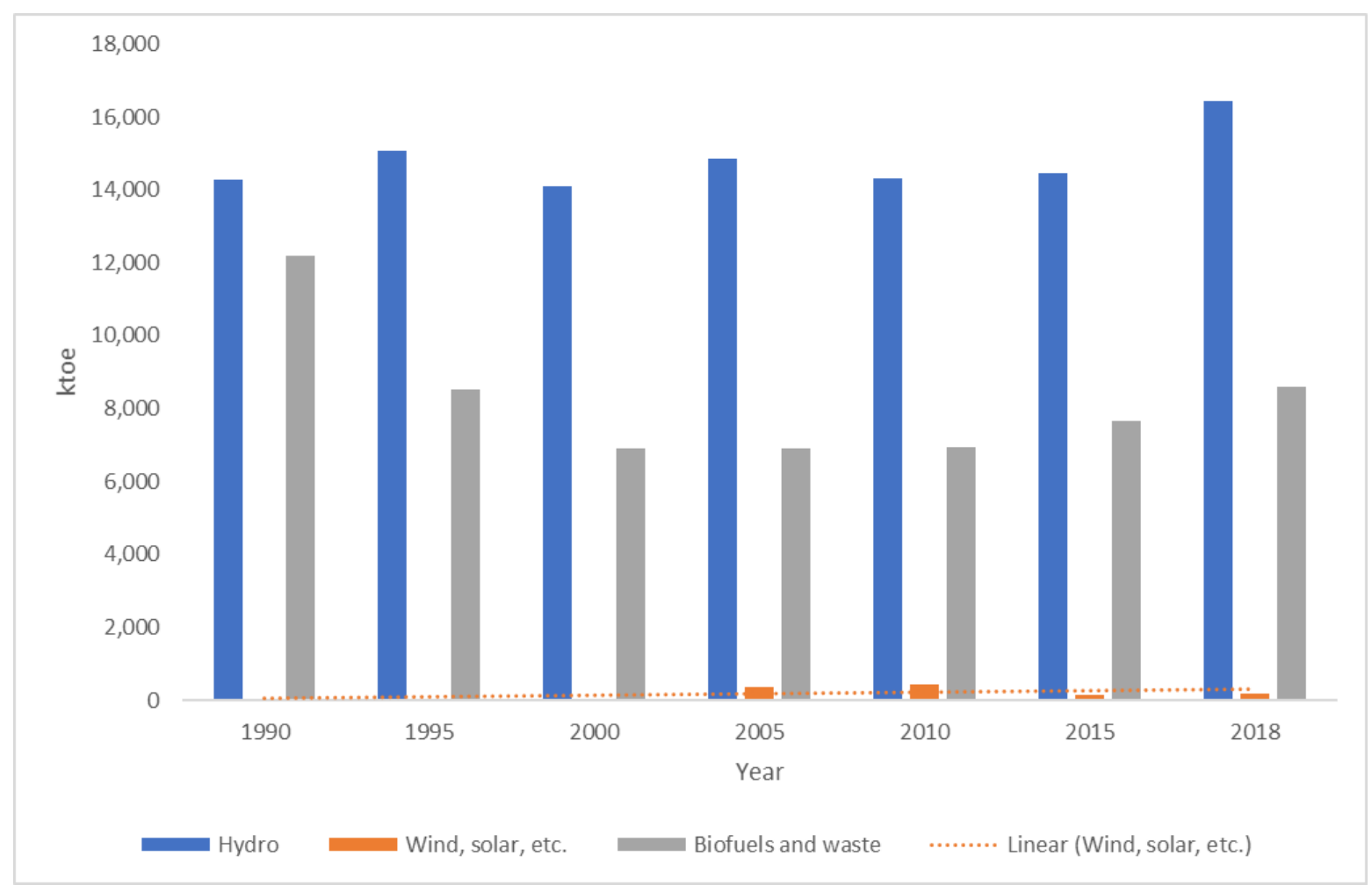

Figure 3. Renewable energy sources development in Russian Federation (with a trend for solar and wind power). Source: own results.

According to the International Energy Agency (IEA), Russia seems to perceive real value in switching from fossil fuels to carbon-free energy sources [79]. To create this incentive, the Russian government must reaffirm its commitment to the decarbonization agenda, which is difficult to achieve without it. According to the International Renewable Energy Agency, the Russian renewable energy sector is likely to remain below $1 \%$ by 2030 [80].

\section{Energy Efficiency and Energy Management}

Energy management activities essentially include the assumption of commitments by the leadership, the development of energy policies, the assessment of energy consumption, the implementation of energy-efficient practices and the monitoring of energy consumption $[81,82]$. All players on the energy markets need to understand the latest information on energy systems management to help the governments save energy costs and achieve their goals for energy efficiency and environmental sustainability. There is a plethora of methods to quantify the impact of effective energy management on energy consumption and greenhouse gas emissions [83,84]. Energy-saving projects can often lead to a significant reduction in energy costs and emissions of greenhouse gases such as carbon dioxide $\left(\mathrm{CO}_{2}\right)$ and methane $\left(\mathrm{CH}_{4}\right)$. Therefore, they are important even for fossil fuel-abundant countries such as Russia [85]. The energy saving can also be carried out using efficient building automation systems that can be used to integrate existing heating, ventilation, and air conditioning (HVAC), lighting and other systems using normalized data and open communication protocols [86]. Careful monitoring and evaluation are required in order to ensure accountability and effectiveness and to foster public confidence in energy efficiency programs. This includes tracking the overall energy consumption before and after modern- 
ization and comparing changes in energy consumption with the expected savings from individual modernization to identify potential system interactions and savings $[87,88]$.

Effective energy management can lead to an increased user comfort and a correctly and efficiently functioning energy system, which is what the Russian energy sector needs. This might help users to assess the impact of energy management practices on their energy efficiency and sustainability. Interactive tools such as the electronic graphics and dashboards provide the opportunity to inform residents about energy and water consumption [89]. Figure 4 that follows offers a blueprint of the modernization of energy efficiency and energy resources in the business enterprises.

Managing the energy consumption and energy resources at the enterprises

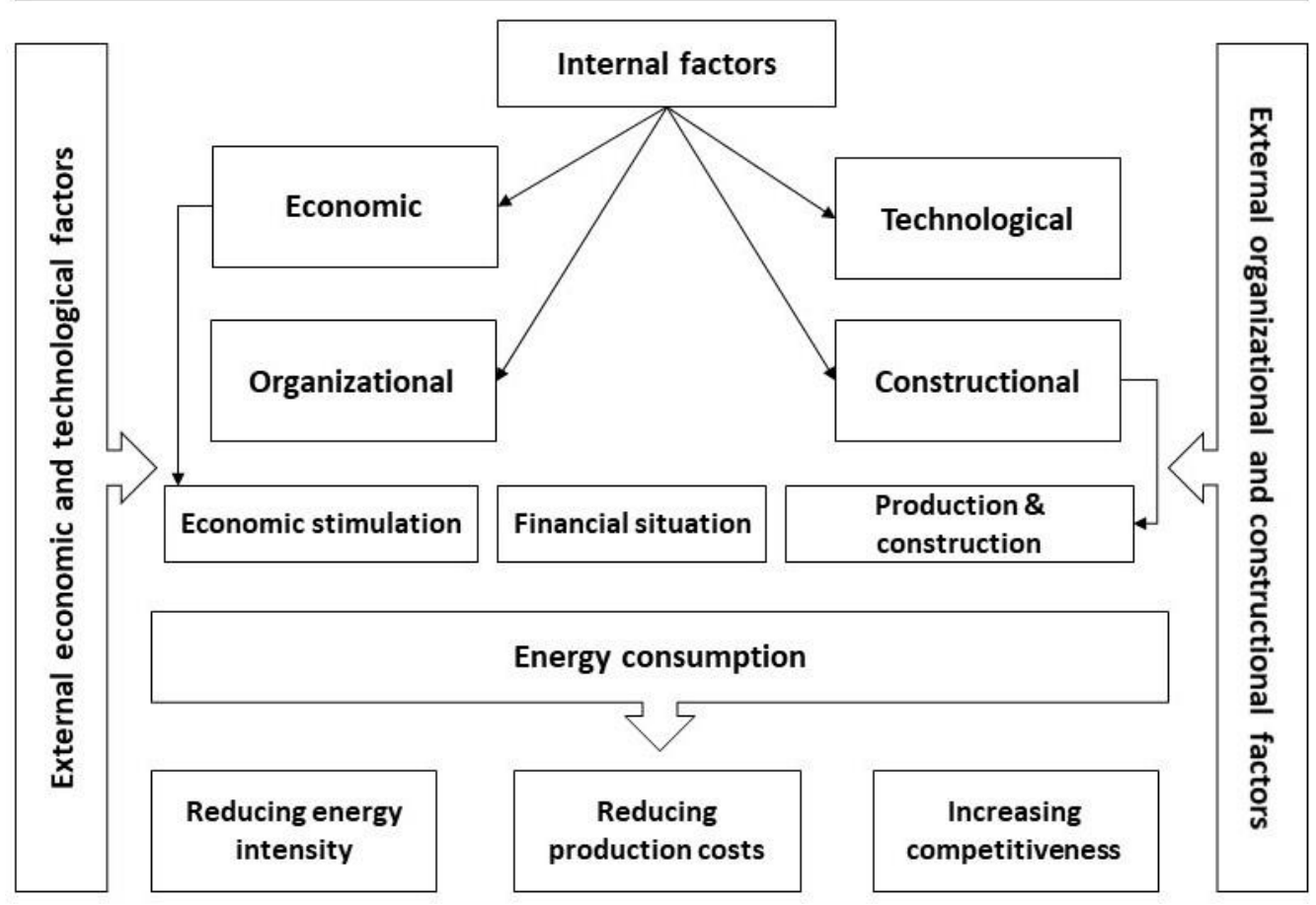

Figure 4. Blueprint of the modernization of energy efficiency. Source: own results.

\subsection{Modernization of Energy Efficiency}

In the Russian energy sector, the consequences of inefficient use of energy resources are faced on a daily basis. Thence, for example, a high level of heat loss occurs due to high wear and imperfections in the design of heating systems. In addition, enterprises suffer huge losses of electricity due to the use of outdated production lines and lighting systems. All of the above leads to the lack of systemic energy monitoring at enterprises, which monitors the use of fuel and energy resources. Manufacturers refer to the lack of free funds that they could use to organize a targeted energy saving policy. In order to solve the problem of increasing energy efficiency, a systematic approach is required. This approach would imply the need to develop a mechanism for the operation of an enterprise that meets modern principles. The mechanism for increasing energy efficiency represents a set of methods, methods, functions, principles and factors that are closely related, with the help of which there is an impact on the efficient use of fuel and energy resources (FERs) and, as a result, on the economic development of enterprises. The main task of the management mechanism is to ensure the most rational use of labor resources, objects and objects of labor. Competent organization of the supply and consumption of fuel and energy resources will lead to a decrease in the energy component, production costs and an increase in the company's profit (see Figure 4). 
Figure 4 demonstrates in a clear graphical manner how the management of energy consumption and energy resources is influenced by the internal and external economic, organizational, technological and construction factors that impact the energy consumption and lead to the reduction in energy intensity and production costs and the increase in competitiveness.

Deep energy renovation and modernization can apply a holistic management approach that can address many systems simultaneously and combine advanced energy management systems [90]. Energy efficiency and renewable energy are placed high on the sustainable energy hierarchy. A comprehensive list of the identified deep energy retrofits and information on the design possibilities are available. Energy efficiency has proven to be a powerful tool for building an economy without necessarily increasing energy consumption which is a lesson the Russian energy sector needs to learn. It is enough to look at some examples from around the world. In the mid-1970s, the state of California in the United States began implementing energy efficiency measures, including the installation of energy-efficient lighting, heating, cooling, air conditioning, and other measures [91]. Energy efficiency is also seen as a national security asset, as it can be used to reduce the level of energy imports from abroad and slow down the use of depleted domestic energy resources. Companies waste more than $80 \%$ of the energy consumed in their commercial buildings, which account for about one-third of all energy-related greenhouse gas emissions, and buildings account for nearly half of global energy consumption [92].

As the complexity of the built infrastructure increases, energy management systems are often used to manage different types of energy loads and optimize the energy efficiency. In large commercial buildings, $50 \%$ of the energy consumption is used to maintain a pleasant environment throughout the day. With regard to that, the demand-side response (DSM) approach aims to minimize energy consumption, reduce maximum demand of the energy consumers, promote greenhouse gas emission reductions, and halt deforestation. The rapidly growing charging demand for electric vehicles has different operating patterns [93].

\subsection{Effective Energy Management Systems in Russia}

Reducing energy demand in Russian energy systems can be achieved through the existing capacity of chargers and battery storage for electric vehicles, as well as through new charging stations for electric vehicles. These methods can reduce electricity bills and meet the requirements for high electricity quality and lower energy costs for consumers [94]. Moreover, another issue in the Russian energy sector is embedding energy efficiency into the day-to-day management techniques of enterprises using effective energy management for managing energy consumption, achieving savings, and continuously improving energy efficiency [95].

As energy use standards become increasingly restrictive, the EMS must be integrated as an effective way of complying with increasing regulations. By installing energy-efficient systems, customers can play a proactive role in reducing energy consumption on behalf of their customers, which is regulated by the International Organization for Standardization (ISO) 50,001 Energy Management Systems international standard as well other standards $[96,97]$. EMS should be considered in conjunction with other energy management systems such as smart thermostats, heat pumps and air conditioning systems. Since energy accounts for $15 \%$ of any plant's total cost, energy management systems can help every business company to save money. By setting up a continuous energy monitoring system, they can reduce the cost of energy consumption by helping companies modernize and adapt air their conditioning, ventilation and heating systems. This cost and usage reduction can be achieved by using intelligent thermostats, sometimes referred to as building management systems. They can also give advice on how to improve the natural lighting in a facility, such as using natural light in the ventilation system, air conditioning and ventilation systems. Energy planning represents one of the most effective ways to increase efficiency, and energy consultants can help reduce energy costs over time. Energy consultants create energy management systems, install new technologies, conduct energy 
audits and conduct an energy audit. All of this can help Russian energy companies to find improvement opportunities and get the best out of their technologies and operation $[98,99]$.

Moreover, energy efficiency of the energy companies in Russia is achieved, among all, through building self-sufficient data centers powered by the renewables that are located in mixed-use buildings, where they often share the same infrastructure and energy supply with other buildings and businesses. This is done due to the vast size of the country and the costs of connecting all new facilities to the grid. Each has a different framework depending on when it was built or renovated, as well as other factors such as the size of the building. With the advent of an advanced measurement infrastructure, the various energy requirements of smart buildings can be coordinated with power plants and the electricity grid $[100,101]$. In order to further exploit the considerable flexibility of energy planning through intelligent construction and intelligently manage the energy load of the building, it is essential to coordinate the behavior of a large number of buildings in order to improve the efficiency and stability of the entire energy system.

In addition, the increasing adoption of smart buildings to optimize energy is expected to boost economic growth not only in Russia but also all around the world. Various national energy efficiency action plans are envisaged to encourage investment in innovative solutions to support the development of energy-efficient buildings, energy efficiency systems and energy management systems. These steps might encourage the large-scale to comply with energy-efficient codes and as an alternative to traditional energy storage and distribution systems. All of the those represent an important lesson that can be implemented even in carbon energy-dependent countries such as the Russian Federation.

\section{Pathways for the Modernization of Power Distribution Electrical Systems in Russia}

Energy saving and modernization of power distribution electrical systems are on the agenda in Russia, with some novel trends emerging. The tools for the Russian energy system transformation and modernization are the country's energy titans [102]. In addition, new and undeveloped fields are being discovered. With the state support, Russian energy companies are developing various technologies to produce and export hydrogen. By developing the hydrogen sector, Russia intends to use existing facilities such as nuclear power stations and nuclear reactors. Russia is the second largest producer and exporter of nuclear energy in the world and plans to build and operate its own state-owned nuclear reactor, which is owned by the state nuclear power agency Rosatom [103]. The state is the majority owner of these companies, although some of them have a degree of autonomy from the government. Most of Russia's largest energy companies, including Gazprom and Rosneft, operate with interests spanning a wide range of industries, from mining and oil production to hydropower and natural gas [104].

In addition, microgeneration, which uses renewable energy for households in Russia, is still largely limited and is explored by the sheer enthusiasts [105]. Russia's economic development is now starting to be driven by the development of renewable energy technologies such as wind and solar power. Almost all major Russian industrial companies, including Gazprom, Russia's largest oil and gas company, or RusHydro, its major hydroelectric company, are developing their own decentralized generation facilities to provide cheaper electricity. This is driven almost exclusively by economic factors and expediency when it comes to the development of renewable energy sources (RES) and technologies.

Another issue in Russian energy and power system is its geopolitical value and importance. Russia is the largest country in the world that has borders with 14 countries. In addition, it is the major player on the European oil market, even though it cannot compete with the Middle East and OPEC countries in oil exports [106]. Here is why the natural gas is becoming the Russian natural resource of the future due to its availability and the growing demand in the key markets.

The influx of foreign developers of renewable energy has stopped, creating a new incentive for local renewable energy entrepreneurs on the Russian market. To create this incentive, the Russian government must reaffirm its commitment to a decarbonization 
agenda that will be difficult to accomplish without it [107]. Many hope that as new oil and gas technologies open up new production opportunities worldwide, the continent will find its way back into the global energy market. That may be true, but the specific route used to pump natural gas to Europe is not particularly important for the country's energy security. More significant is the additional contribution of Russian gas production to global supply, which will boost global supply and drive up prices for European consumers. The energy sector is a major investment factor around the world, accounting for more than one-third of Russia's gross domestic product. The country has one of the largest oil and gas reserves in the world that can also last for several more decades. Major Russian oil and gas companies helped fuel Russian economy, based on an ongoing National Technology Initiative, the components of which are called the Energy Net Roadmap. Russia's electricity grid is to be modernized and upgraded with up to USD 40 billion annually by 2035 . Billions of rubles were invested in the electricity modernization program which were a part of the preparation to the Winter Olympic Games in Sochi (2014).

\subsection{Plans and Initiatives for the Modernization of the Electric Power Sector in Russia}

Concrete plans for the efforts leading to the modernization of the Russian energy sector can be found in a report by the Russian Energy Ministry entitled "Russian Energy Strategy for 2035". In 2011, the Russian Prime Minister asked his Energy Minister to draft a government resolution that would limit the profitability of electricity utilities. Several years later, Russia's energy outlook for 2035 was adopted, and price increases at the Energy Ministry and Russia's largest electricity company, Gazprom, remain a concern [108,109]. The Russian government will need USD 350-500 billion to modernize its grid infrastructure nationwide, and will increase financing for infrastructure projects and the tens of billions of dollars that will be invested through loan and guarantee programs [110]. Additional funds would be needed for re-training specialists in the new energy technologies and policies or for replacing the aging workforce in the energy sector. Moreover, the Russian government is planning to expand the current initiatives for integration and optimization of distribution network technologies as well as to create the new standards for cybersecurity and smart metering.

Furthermore, Russia recognizes the strategic and economic importance of nuclear power. For this reason, it reaffirmed its commitment to modernize and expand its nuclear fleet, announcing a plan to invest USD 1.3 billion in nuclear research and development, compared with a figure proposed in 2007 [111]. All this calls for a comprehensive plan to modernize and strengthen the electricity grid. Specific objectives include the installation of a lead-cooled fast-reaction reactor with a capacity of $1,000 \mathrm{MW}$, which is to be built as part of a nationally planned 1-200 MW reactor at the first Russian nuclear power plant [112]. The country is also taking significant steps to free itself from restricted access to nuclear energy for the first time in its history, as can be seen from the Russian nuclear mission. The plan, which envisages a 50\% reduction in the number of nuclear reactors by 2030, includes the further development of nuclear technology and the closing of the nuclear cycle. Nuclear power is expected to yield at least one-third of the country's total electricity generation capacity by 2050 [113].

Apart from all the arguments provided above, there are the also some obvious geopolitical concerns that burden the modernization of the Russian energy sector and their transition to the renewable energy. However, we left geopolitics outside the scope of our paper. Instead, we would rather concentrate on the concrete recommendations for the modernization of distribution electrical power systems in Russia.

\subsection{Main Obstacles and Reasons for the Electrical Power Sector in Russia}

At the moment, there is an ongoing stagnation of the Russian power and engineering sector, which has led to its growing inefficiency marked by the higher tariffs and electricity prices for the end consumers [114-116]. This can, with a high degree of probability, become a constraining factor for the development of the Russian economy, a significant part of 
which is based on energy-intensive production. The challenge is exacerbated by the fact that today's energy consumers in Russia are becoming more demanding in terms of availability, reliability and quality of electricity (which became more apparent during the COVID-19 pandemic) $[117,118]$. With regard to this, it should be understood that it is difficult for an industry based on traditional technologies to significantly increase its efficiency, as well as to meet new consumer requirements without a noticeable increase in prices. At the same time, there is reason to believe that a new technology is capable of responding to this challenge, ensuring the transition from analog to digital control methods in the electric power industry and supporting the transformation of consumer behavior models, as well as business practices of energy supply and service companies.

Thus, the new strategy that needs to adapted by the Russian policy makers and energy stakeholders might consist of establishing a new technological paradigm based on the formation of a market ecosystem of active consumers, prosumers and other subjects of the distributed energy market on the basis of a smart infrastructure, which should become a priority for the transformation of the Russian electric power industry $[119,120]$. Such a transition will help to mobilize entrepreneurial initiatives in the industry and attract private investment, put "creative pressure" on the electricity infrastructure, and increase the level of competition in the energy markets [121,122].

Nevertheless, an obstacle to the implementation of this novel strategy might be that under the current institutional environment that prevails in Russia, the main energy market actors and infrastructure organizations are generally not interested in the transition to a new technological package and to a new architecture in the industry [123,124]. At the same time, retail consumers and distributed energy entities often remain outside the field of the competitive mechanisms and face regulatory barriers for the implementation of the new technological approaches to energy supply.

\section{Conclusions and Implications}

Overall, it is apparent that the Russian energy sector plays a significant role in the formation of the country's GDP. In addition, experience with investment and innovation deficit have a high degree of import dependence against the background of an unfavorable political and economic situation for the Russian Federation. This calls for the systematic modernization of fixed assets that represent the sources of destabilization of the environmental situation and that constitute the socially significant objects of the economy being the largest consumers of fuel and energy resources with a fairly low level of energy efficiency in comparison with the developed countries.

The peculiarities of the functioning of the modern Russian energy sector indicate the pressing need to ensuring its sustainable economic development in terms of the economic, environmental and social components. The unsatisfactory indicators of energy efficiency in the industrial enterprises are due to a number of reasons, among which are the lack of development of organizational and economic mechanisms for energy efficiency management, which is aimed at ensuring the sustainable development of the economy and steady economic growth.

It appears that one of the most promising areas for improving energy efficiency and modernization of the Russian energy sector lies in the introduction of an organizational and economic mechanism for managing energy efficiency based on the international requirements. Considering the nature of Russian economy and politics, it is more likely that these mechanisms can be installed from above rather than created from below.

Yet another important aspect of modernization of the Russian electrical power industry is the transition towards the renewable energy that would include introduction of elements smart grids, distributed energy generation and peer-to-peer energy trading between consumers. As far as the policy implications are concerned, it becomes apparent that the country needs to embark on a path of digitalization in energy industry and increase the share of renewables in its energy mix. All of these constitute serious challenges for the Russian energy sector as well as the problems of energy efficiency and energy saving 
in Russian business enterprises that need to be tackled by the politicians and business stakeholders.

Therefore, it can be deduced that for the modernization of the Russian electric power industry should be conducted through the changes in the retail segment of the electricity market, deregulation of the electricity market, introduction of the easy-to-use interfaces for the technological and information interactions of distributed energy facilities, as well as through the creation of the effective distribution mechanisms. The following aspects can be recommended as the medium-term objectives for the Russian state policy in the electric power industry:

- Launching open modular digital platforms for organizing cyber-physical systems and environments in the power industry;

- Developing the intelligent multi-agent control systems;

- Formation of the market segment of energy storage systems (from batteries for electric vehicles and the household sector to large energy storage systems capacities, including technologies for storing electricity in the hydrogen cycle);

- Developing the advanced high-voltage and high-frequency power electronics sector;

- Introducing the technologies leading to the "Internet of Things" (e.g., digital sensors, sensors, actuators and communication tools);

- Using digital financial technologies (blockchain, smart contracts, decentralized autonomous organizations).

When it comes to the perspective related to the future research work, the study of increasing energy efficiency and modernization of the Russian energy sector might put a emphasis on introducing renewable energy sources that might be beneficial by assessing the role of the carbon pricing and carbon taxes. Currently, it is clear that, given the recent prices of oil and gas, the Russian economy would hardly substitute these with RESs at a large scale (the same applies to the energy consumers). However, assuming that some carbon tax would be introduced in Russia, making the electricity generated from the carbon-intensive sources more expensive, many incentives for the renewable energy projects would appear. The question is how high should this be carbon tax be and what mechanisms should it use in order not to leave the consumers worse off?

Regarding the pathways for further research, two important suggestions can be made for the researchers pursuing the same topic. First of all, it would be interesting to assess the potential for clean and renewable energy in various parts of the Russian Federation. Given the size of the country and the number of the climate zones on its territory, it may be interesting to compare their perspectives with regard to the modernization of the energy sector and the promotion of the specific types of RESs. Second, it might be interesting to analyze the possibilities of not only modernizing but also decentralizing the electrical power networks in Russia using distributed generation, microgrids and peer-to-peer (P2P) networks. These topics deserve further attention and do not seem to be well covered in the current research literature related to energy sector modernization in Russia.

Author Contributions: Conceptualization, W.S., A.S., P.R. and T.E.; methodology, W.S., A.S., P.R., and T.E.; formal analysis, W.S., A.S. and P.R.; resources, P.R. and T.E.; data curation, W.S., A.S. and P.R.; writing—original draft preparation, W.S., A.S., P.R. and T.E.; writing—review and editing, W.S., A.S., P.R., and T.E.; visualization, W.S. All authors have read and agreed to the published version of the manuscript.

Funding: This research received no external funding.

Institutional Review Board Statement: Not applicable.

Informed Consent Statement: Not applicable.

Data Availability Statement: Data available from the authors upon request.

Conflicts of Interest: The authors declare no conflict of interest. 


\section{References}

1. Dunlop, T. Mind the gap: A social sciences review of energy efficiency. Energy Res. Soc. Sci. 2019, 56, 101216. [CrossRef]

2. Huber, R.A.; Maltby, T.; Szulecki, K.; Ćetković, S. Is populism a challenge to European energy and climate policy? Empirical evidence across varieties of populism. J. Eur. Public Policy 2021, 1-20. [CrossRef]

3. Dell'Anna, F. Green jobs and energy efficiency as strategies for economic growth and the reduction of environmental impacts. Energy Policy 2020, 149, 112031. [CrossRef]

4. Newbery, D.; Pollitt, M.G.; Ritz, R.A.; Strielkowski, W. Market design for a high-renewables European electricity system. Renew. Sustain. Energy Rev. 2018, 91, 695-707. [CrossRef]

5. McElroy, D.J.; Rosenow, J. Policy implications for the performance gap of low-carbon building technologies. Build. Res. Inf. 2019, 47, 611-623. [CrossRef]

6. Marinakis, V. Big data for energy management and energy-efficient buildings. Energies 2020, 13, 1555. [CrossRef]

7. Bertoldi, P.; Mosconi, R. Do energy efficiency policies save energy? A new approach based on energy policy indicators (in the EU Member States). Energy Policy 2020, 139, 111320. [CrossRef]

8. Yao, Y.; Xu, J.H.; Sun, D.Q. Untangling global levelised cost of electricity based on multi-factor learning curve for renewable energy: Wind, solar, geothermal, hydropower and bioenergy. J. Clean. Prod. 2021, 285, 124827. [CrossRef]

9. Füllemann, Y.; Moreau, V.; Vielle, M.; Vuille, F. Hire fast, fire slow: The employment benefits of energy transitions. Econ. Syst. Res. 2020, 32, 202-220. [CrossRef]

10. Zou, P.X.; Wagle, D.; Alam, M. Strategies for minimizing building energy performance gaps between the design intend and the reality. Energy Build. 2019, 191, 31-41. [CrossRef]

11. Killip, G.; Owen, A.; Topouzi, M. Exploring the practices and roles of UK construction manufacturers and merchants in relation to housing energy retrofit. J. Clean. Prod. 2020, 251, 119205. [CrossRef]

12. Gunawan, J.; Permatasari, P.; Tilt, C. Sustainable development goal disclosures: Do they support responsible consumption and production? J. Clean. Prod. 2020, 246, 118989. [CrossRef]

13. Wu, H.; Hao, Y.; Ren, S. How do environmental regulation and environmental decentralization affect green total factor energy efficiency: Evidence from China. Energy Econ. 2020, 91, 104880. [CrossRef]

14. Kraus, S.; Burtscher, J.; Vallaster, C.; Angerer, M. Sustainable entrepreneurship orientation: A reflection on status-quo research on factors facilitating responsible managerial practices. Sustainability 2018, 10, 444. [CrossRef]

15. Yong, J.Y.; Yusliza, M.Y.; Ramayah, T.; Chiappetta Jabbour, C.J.; Sehnem, S.; Mani, V. Pathways towards sustainability in manufacturing organizations: Empirical evidence on the role of green human resource management. Bus. Strategy Environ. 2020, 29, 212-228. [CrossRef]

16. Johnstone, P.; Rogge, K.S.; Kivimaa, P.; Fratini, C.F.; Primmer, E.; Stirling, A. Waves of disruption in clean energy transitions: Sociotechnical dimensions of system disruption in Germany and the United Kingdom. Energy Res. Soc. Sci. 2020, $59,101287$. [CrossRef]

17. Heikkurinen, P.; Young, C.W.; Morgan, E. Business for sustainable change: Extending eco-efficiency and eco-sufficiency strategies to consumers. J. Clean. Prod. 2019, 218, 656-664. [CrossRef]

18. Alam, M.; Zou, P.X.; Stewart, R.A.; Bertone, E.; Sahin, O.; Buntine, C.; Marshall, C. Government championed strategies to overcome the barriers to public building energy efficiency retrofit projects. Sustain. Cities Soc. 2019, 44, 56-69. [CrossRef]

19. Palm, J.; Backman, F. Energy efficiency in SMEs: Overcoming the communication barrier. Energy Effic. 2020, 13, 1-13. [CrossRef]

20. Tronchin, L.; Manfren, M.; Nastasi, B. Energy efficiency, demand side management and energy storage technologies-A critical analysis of possible paths of integration in the built environment. Renew. Sustain. Energy Rev. 2018, 95, 341-353. [CrossRef]

21. Javaid, S.; Javaid, N. Comfort evaluation of seasonally and daily used residential load in smart buildings for hottest areas via predictive mean vote method. Sustain. Comput. Inform. Syst. 2020, 25, 100369. [CrossRef]

22. Strielkowski, W.; Veinbender, T.; Tvaronavičienė, M.; Lace, N. Economic efficiency and energy security of smart cities. Econ. Res. Ekon. Istraživanja 2020, 33, 788-803. [CrossRef]

23. Alekseev, A.N.; Lobova, S.V.; Bogoviz, A.V.; Ragulina, Y.V. Digitalization of the Russian energy sector: State-of-the-art and potential for future research. Int. J. Energy Econ. Policy 2019, 9, 274. [CrossRef]

24. Kapustin, N.O.; Grushevenko, D.A. Exploring the implications of Russian Energy Strategy project for oil refining sector. Energy Policy 2018, 117, 198-207. [CrossRef]

25. Makarov, A.A. Half a Century of Systems Studies into Developing the Power Industry in the Soviet Union and Russia: What Next? Therm. Eng. 2020, 67, 863-871. [CrossRef]

26. Gokhberg, L.; Sokolov, A. Technology foresight in Russia in historical evolutionary perspective. Technol. Forecast. Soc. Chang. 2017, 119, 256-267. [CrossRef]

27. Proskuryakova, L.N.; Ermolenko, G.V. The future of Russia's renewable energy sector: Trends, scenarios and policies. Renew. Energy 2019, 143, 1670-1686. [CrossRef]

28. Westphal, K. German-Russian gas relations in face of the energy transition. Russ. J. Econ. 2020, 6, 406-423. [CrossRef]

29. Mitrova, T.; Melnikov, Y. Energy transition in Russia. Energy Transit. 2019, 3, 73-80. [CrossRef]

30. Proedrou, F. Russian energy policy and structural power in Europe. Eur. Asia Stud. 2018, 70, 75-89. [CrossRef]

31. Favorskii, O.N.; Batenin, V.M.; Maslennikov, V.M. Where to Start the Implementation of Russia's Energy Strategy. Her. Russ. Acad. Sci. 2015, 85, 1-7. [CrossRef] 
32. Proskuryakova, L.; Starodubtseva, A.; Bianco, V. Modelling a household tariff for reducing sectoral cross-subsidies in the Russian power market. Energy 2020, 213, 118725. [CrossRef]

33. Asaul, A.N.; Asaul, M.A.; Levin, Y.A.; Platonov, A.M. Energy Supply to Isolated Areas: Attracting Investment and Developing Regional Economy. Econ. Reg. 2020, 3, 884-895. [CrossRef]

34. Lisin, E.; Kindra, V.; Zlyvko, O.; Strielkowski, W.; Bartkute, R. Economic analysis of heat and electricity production in the decentralisation of the Russian energy sector. Transform. Bus. Econ. 2017, 16, 75-88.

35. Gazprom. Gasification of Russian Regions. 2020. Available online: https://mrg.gazprom.ru/about/gasification (accessed on 12 May 2021).

36. Palyanova, N.V.; Zadkov, D.A.; Chubukova, S.G. Legal framework for the sustainable economic and ecological development in the coal industry in Russia. Eurasian Min. 2017, 1, 3-5. [CrossRef]

37. Sorokin, A.P.; Konyushok, A.A.; Ageev, O.A.; Zarubina, N.V.; Ivanov, V.V.; Wang, J. Distribution of rare earth and selected trace elements in combustion products of Yerkovetskoe brown coal deposit (Amur Region, Russia). Energy Explor. Exploit. 2019, 37, 1721-1736. [CrossRef]

38. UNECE. Russian Coal Sector. 2002. Available online: https://unece.org/ (accessed on 10 May 2021).

39. Nevskaya, M.A.; Seleznev, S.G.; Masloboev, V.A.; Klyuchnikova, E.M.; Makarov, D.V. Environmental and business challenges presented by mining and mineral processing waste in the Russian Federation. Minerals 2019, 9, 445. [CrossRef]

40. Tsepelev, O.A.; Serikov, S.G. Peculiarities of Regional Development and Industrial Specialization of the Far East of Russia. J. Appl. Econ. Sci. 2017, 12, 1301-1311.

41. Lisin, E.; Strielkowski, W.; Krivokora, E. Economic Analysis of Industrial Development: A Case of Russian Coal Industry. Montenegrin J. Econ. 2016, 12, 129-139. [CrossRef]

42. Aalto, P.; Forsberg, T. The structuration of Russia's geo-economy under economic sanctions. Asia Eur. J. 2016, 14, 221-237. [CrossRef]

43. Karatayev, M.; Hall, S. Establishing and comparing energy security trends in resource-rich exporting nations (Russia and the Caspian Sea region). Resour. Policy 2020, 68, 101746. [CrossRef]

44. Makarov, I.; Chen, H.; Paltsev, S. Impacts of climate change policies worldwide on the Russian economy. Clim. Policy 2020, 20, 1242-1256. [CrossRef]

45. Bradshaw, M.; Van de Graaf, T.; Connolly, R. Preparing for the new oil order? Saudi Arabia and Russia. Energy Strategy Rev. 2019, 26, 100374. [CrossRef]

46. Polyakova, A.G.; Ramakrishna, S.A.; Kolmakov, V.V.; Zavyalov, D.V. A model of fuel and energy sector contribution to economic growth. Int. J. Energy Econ. Policy 2019, 9, 25-31. [CrossRef]

47. Siddi, M. The role of power in EU-Russia energy relations: The interplay between markets and geopolitics. Eur. Asia Stud. 2018, 70, 1552-1571. [CrossRef]

48. Makarov, A.A. Technological progress opportunities in the energy sector of Russia. Stud. Russ. Econ. Dev. 2020, 31, 52-63. [CrossRef]

49. Grouiez, P.; Vercueil, J.; Volkov, D.D. Beyond oil: The international integration of the Russian economy between macroeconomic constraints and sectoral dynamics. Post Communist Econ. 2021, 1-25. [CrossRef]

50. European Commission. European Economic Forecast. 2020. Available online: https://ec.europa.eu/info/sites/default/files/ economy-finance/ip125_en.pdf (accessed on 12 May 2021).

51. IEA. Russia: Country Profile. Available online: https://www.iea.org/countries/russia (accessed on 21 February 2021).

52. Shalaeva, D.S.; Kukartseva, O.I.; Tynchenko, V.S.; Kukartsev, V.V.; Aponasenko, S.V.; Stepanova, E.V. Analysis of the development of global energy production and consumption by fuel type in various regions of the world. IOP Conf. Ser. Mater. Sci. Eng. 2020, 952, 012025. [CrossRef]

53. Arens, M.; Åhman, M.; Vogl, V. Which countries are prepared to green their coal-based steel industry with electricity?-Reviewing climate and energy policy as well as the implementation of renewable electricity. Renew. Sustain. Energy Rev. 2021, 143, 110938. [CrossRef]

54. Yennie-Lindgren, W. New dynamics in Japan-Russia energy relations 2011-2017. J. Eurasian Stud. 2018, 9, 152-162. [CrossRef]

55. Ministry of Energy of Russian Federation. 2021 Energy Statistics. Available online: https://minenergo.gov.ru/activity/statistic (accessed on 20 May 2021).

56. Aalto, P.; Nyyssönen, H.; Kojo, M.; Pal, P. Russian nuclear energy diplomacy in Finland and Hungary. Eurasian Geogr. Econ. 2017, 58, 386-417. [CrossRef]

57. Wu, X.F.; Chen, G.Q. Coal use embodied in globalized world economy: From source to sink through supply chain. Renew. Sustain. Energy Rev. 2018, 81, 978-993. [CrossRef]

58. Kan, S.Y.; Chen, B.; Wu, X.F.; Chen, Z.M.; Chen, G.Q. Natural gas overview for world economy: From primary supply to final demand via global supply chains. Energy Policy 2019, 124, 215-225. [CrossRef]

59. World Bank. Electric Power Consumption-Russian Federation. 2021. Available online: https://data.worldbank.org/indicator (accessed on 12 October 2021).

60. Rodionova, I.; Kokuytseva, T.; Shuvalova, O. Innovative energy policy of the of the Eurasian Economic Union member countries. E3S Web Conf. 2020, 159, 02002. [CrossRef] 
61. Jääskeläinen, J.J.; Höysniemi, S.; Syri, S.; Tynkkynen, V.P. Finland's dependence on Russian energy-Mutually beneficial trade relations or an energy security threat? Sustainability 2018, 10, 3445. [CrossRef]

62. Lüthi, L.M. Drifting Apart: Soviet Energy and the Cohesion of the Communist Bloc in the 1970s and 1980s. Cold War Energy; Palgrave Macmillan: Cham, Switzerland, 2017; pp. 371-399. [CrossRef]

63. De Groot, M. The Soviet Union, CMEA, and the Energy Crisis of the 1970s. J. Cold War Stud. 2020, 22, 4-30. [CrossRef]

64. Lezier, V.; Gusarova, M.; Kopytova, A. Energy management in modern Russia: Problems, development trends, prospects. IOP Conf. Ser. Earth Environ. Sci. 2017, 90, 012034. [CrossRef]

65. Josefson, J.; Rotar, A.; Lewis, M. Electricity Regulation in the Russian Federation: Overview. 2020. Available online: https: / / uk.practicallaw.thomsonreuters.com/6-527-2969?transitionType=Default\&contextData=(sc.Default) (accessed on 20 February 2021).

66. Gitelman, L.; Magaril, E.; Kozhevnikov, M.; Rada, E.C. Rational behavior of an enterprise in the energy market in a circular economy. Resources 2019, 8, 73. [CrossRef]

67. Zotkina, N.; Gusarova, M.; Kopytova, A. Labor Management in Organizational Structures of Russian Energy Enterprises. In Energy Management of Municipal Transportation Facilities and Transport; Springer: Cham, Switzerland, 2017; pp. 1204-1213. [CrossRef]

68. Matraeva, L.; Solodukha, P.; Erokhin, S.; Babenko, M. Improvement of Russian energy efficiency strategy within the framework of "green economy" concept (based on the analysis of experience of foreign countries). Energy Policy 2019, 125, 478-486. [CrossRef]

69. Koch, N.; Tynkkynen, V.P. The geopolitics of renewables in Kazakhstan and Russia. Geopolitics 2019, 1-20. [CrossRef]

70. An, J.; Dorofeev, M.; Zhu, S. Development of energy cooperation between Russia and China. Int. J. Energy Econ. Policy 2020, 10, 134. [CrossRef]

71. Smeets, N. The Green Menace: Unraveling Russia's elite discourse on enabling and constraining factors of renewable energy policies. Energy Res. Soc. Sci. 2018, 40, 244-256. [CrossRef]

72. Talipova, A.; Parsegov, S.G.; Tukpetov, P. Russian gas exchange: A new indicator of market efficiency and competition or the instrument of monopolist? Energy Policy 2019, 135, 111012. [CrossRef]

73. Grigoryev, L.M.; Medzhidova, D.D. Global energy trilemma. Russ. J. Econ. 2020, 6, 437-462. [CrossRef]

74. Dudin, M.N.; Zasko, V.N.; Dontsova, O.I.; Osokina, I.V. The energy politics of the european union and the possibility to implement it in post-soviet states. Int. J. Energy Econ. Policy 2020, 10, 409-416. [CrossRef]

75. Ministry of Economic Development of Russia. 2019 Report on the on the State of Energy Conservation and Energy Efficiency in the Russian Federation. Available online: https: / / economy.gov.ru/material/file/c3901dba442f8e361d68bc019d7ee83f/ Energyefficiency2020.pdf (accessed on 14 May 2021).

76. Gavrikova, E.; Burda, Y.; Gavrikov, V.; Sharafutdinov, R.; Volkova, I.; Rubleva, M.; Polosukhina, D. Clean energy sources: Insights from Russia. Resources 2019, 8, 84. [CrossRef]

77. Lanshina, T.A.; John, A.; Potashnikov, V.Y.; Barinova, V.A. The slow expansion of renewable energy in Russia: Competitiveness and regulation issues. Energy Policy 2018, 120, 600-609. [CrossRef]

78. Chebotareva, G.; Strielkowski, W.; Streimikiene, D. Risk assessment in renewable energy projects: A case of Russia. J. Clean. Prod. 2020, 269, 122110. [CrossRef]

79. Mitrova, T.; Melnikov, Y. A carbon-free world-What is Russia's response? Annales des Mines 2019, 3, 128-132. [CrossRef]

80. IRENA. Renewable Energy Prospects for the Russian Federation. Available online: https://www.irena.org/-/media/Files/ IRENA/Agency/Publication/2017/Apr/IRENA_REmap_Russia_paper_2017.pdf (accessed on 24 February 2021).

81. Trianni, A.; Cagno, E.; Bertolotti, M.; Thollander, P.; Andersson, E. Energy management: A practice-based assessment model. Appl. Energy 2019, 235, 1614-1636. [CrossRef]

82. Cooremans, C.; Schönenberger, A. Energy management: A key driver of energy-efficiency investment? J. Clean. Prod. 2019, 230, 264-275. [CrossRef]

83. Iris, Ç.; Lam, J.S.L. A review of energy efficiency in ports: Operational strategies, technologies and energy management systems. Renew. Sustain. Energy Rev. 2019, 112, 170-182. [CrossRef]

84. Sarkodie, S.A.; Strezov, V. Effect of foreign direct investments, economic development and energy consumption on greenhouse gas emissions in developing countries. Sci. Total Environ. 2019, 646, 862-871. [CrossRef] [PubMed]

85. Mikhaylov, A.; Moiseev, N.; Aleshin, K.; Burkhardt, T. Global climate change and greenhouse effect. Entrep. Sustain. Issues 2020, 7, 2897-2913. [CrossRef]

86. Han, K.; Zhang, J. Energy-saving building system integration with a smart and low-cost sensing/control network for sustainable and healthy living environments: Demonstration case study. Energy Build. 2020, 214, 109861. [CrossRef]

87. Töppel, J.; Tränkler, T. Modeling energy efficiency insurances and energy performance contracts for a quantitative comparison of risk mitigation potential. Energy Econ. 2019, 80, 842-859. [CrossRef]

88. Strielkowski, W.; Firsova, I.; Lukashenko, I.; Raudeliūnienė, J.; Tvaronavičienė, M. Effective Management of Energy Consumption during the COVID-19 Pandemic: The Role of ICT Solutions. Energies 2021, 14, 893. [CrossRef]

89. Rathor, S.K.; Saxena, D. Energy management system for smart grid: An overview and key issues. Int. J. Energy Res. 2020, 44, 4067-4109. [CrossRef]

90. Dodoo, A.; Gustavsson, L.; Tettey, U.Y. Final energy savings and cost-effectiveness of deep energy renovation of a multi-storey residential building. Energy 2017, 135, 563-576. [CrossRef] 
91. Mahyudin, N.K.B.; Zaini, Z.H.; Salleh, M.K.M.; Ahmad, A. A study of electrical energy efficiency building. J. Eng. Health Sci. 2019, 2, 9-18.

92. Elavarasan, R.M.; Afridhis, S.; Vijayaraghavan, R.R.; Subramaniam, U.; Nurunnabi, M. SWOT analysis: A framework for comprehensive evaluation of drivers and barriers for renewable energy development in significant countries. Energy Rep. 2020, 6, 1838-1864. [CrossRef]

93. Blok, K.; Afanador, A.; Van Der Hoorn, I.; Berg, T.; Edelenbosch, O.Y.; Van Vuuren, D.P. Assessment of sectoral greenhouse gas emission reduction potentials for 2030. Energies 2020, 13, 943. [CrossRef]

94. Mehrjerdi, H.; Hemmati, R. Stochastic model for electric vehicle charging station integrated with wind energy. Sustainable Energy Technol. Assess. 2020, 37, 100577. [CrossRef]

95. Al-Ali, A.R.; Zualkernan, I.A.; Rashid, M.; Gupta, R.; Alikarar, M. A smart home energy management system using IoT and big data analytics approach. IEEE Trans. Consum. Electron. 2017, 63, 426-434. [CrossRef]

96. Lai, C.S.; Jia, Y.; Dong, Z.; Wang, D.; Tao, Y.; Lai, Q.H.; Lai, L.L. A review of technical standards for smart cities. Clean Technol. 2020, 2, 19. [CrossRef]

97. Marimon, F.; Casadesús, M. Reasons to adopt ISO 50001 energy management system. Sustainability 2017, 9, 1740. [CrossRef]

98. Gui, E.M.; MacGill, I. Typology of future clean energy communities: An exploratory structure, opportunities, and challenges. Energy Res. Soc. Sci. 2018, 35, 94-107. [CrossRef]

99. Sun, J.; Li, M.; Zhang, Z.; Xu, T.; He, J.; Wang, H.; Li, G. Renewable energy transmission by HVDC across the continent: System challenges and opportunities. CSEE J. Power Energy Syst. 2017, 3, 353-364. [CrossRef]

100. Al Dakheel, J.; Del Pero, C.; Aste, N.; Leonforte, F. Smart buildings features and key performance indicators: A review. Sustain. Cities Soc. 2020, 102328. [CrossRef]

101. Tishkov, S.; Shcherbak, A.; Karginova-Gubinova, V.; Volkov, A.; Tleppayev, A.; Pakhomova, A. Assessment the role of renewable energy in socio-economic development of rural and Arctic regions. Entrep. Sustain. Issues 2020, 7, 3354-3368. [CrossRef]

102. Dementieva, A. Corporate Sector in Russia: What Happened and What Is Ahead Analysis. In Corporate Governance in Central Europe and Russia; Springer: Cham, Switzerland, 2020; pp. 199-217. [CrossRef]

103. Kirillova, O.S. Local Content Within Extractive Resources Industry in the Russian Federation. In Sovereign Wealth Funds, Local Content Policies and CSR; Springer: Cham, Switzerland, 2021; pp. 359-369. [CrossRef]

104. Mikhailov, V.E.; Ivanchenko, I.P.; Prokopenko, A.N. Modern State of Hydropower and Construction of Hydro Turbines in Russia and Abroad. Therm. Eng. 2021, 68, 83-93. [CrossRef]

105. Gomonov, K.G.; Sipakova, P.O.; Chapurnaya, A.P. Introduction of microgeneration and energy-saving technologies within the concept of green economy: Foreign experience and Russia. RUDN J. Econ. 2019, 27, 442-454. [CrossRef]

106. Laitner, J.A.; Lugovoy, O.V.; Potashnikov, V.Y. Cost and Benefits of Deep Decarbonization in Russia. Econ. Policy 2020, 15, 86-106. [CrossRef]

107. Letova, K.; Yao, R.; Davidson, M.; Afanasyeva, E. A review of electricity markets and reforms in Russia. Util. Policy 2018, 53, 84-93. [CrossRef]

108. Zhiznin, S.Z.; Timokhov, V.M.; Gusev, A.L. Economic aspects of nuclear and hydrogen energy in the world and Russia. Int. J. Hydrog. Energy 2020, 45, 31353-31366. [CrossRef]

109. Goremyshev, A.; Kapustkin, V. World Nuclear Energy Development Trends and Russia's Competitiveness at the Global Nuclear Market. Third International Economic Symposium (IES 2018); Atlantis Press: Paris, France, 2019; pp. 57-67. [CrossRef]

110. Vershitsky, A.; Egorova, M.; Platonova;, S.; Berezniak, I.; Zatsarinnaya, E. Municipal infrastructure management using smart city technologies. Theor. Empir. Res. Urban Manag. 2021, 16, 20-39.

111. World Nuclear Association. Nuclear Power in Russia. 2021. Available online: https://www.world-nuclear.org/informationlibrary/country-profiles/countries-o-s/russia-nuclear-power.aspx (accessed on 3 April 2021).

112. Safonov, G.; Potashnikov, V.; Lugovoy, O.; Safonov, M.; Dorina, A.; Bolotov, A. The low carbon development options for Russia. Clim. Change 2020, 162, 1929-1945. [CrossRef]

113. Ho, M.; Obbard, E.; Burr, P.A.; Yeoh, G. A review on the development of nuclear power reactors. Energy Procedia 2019, 160, 459-466. [CrossRef]

114. Akhmetshin, E.M.; Kopylov, S.I.; Lobova, S.V.; Panchenko, N.B.; Kostyleva, G. Specifics of the fuel and energy complex regulation: Seeking new opportunities for Russian and international aspects. Int. J. Energy Econ. Policy 2018, 8, 169-177.

115. Gusev, A. New cyberattacks vectors of Russian critical infrastructure enterprises: Domestic private banking sector view within AI protection methods. Procedia Comput. Sci. 2020, 169, 314-319. [CrossRef]

116. Chukreyev, M. Power price in the conditions of market relations UES of Russia. E3S Web Conf. 2020, 216, 01047. [CrossRef]

117. Kulachinskaya, A.; Akhmetova, I.G.; Kulkova, V.Y.; Ilyashenko, S.B. The Challenge of the Energy Sector of Russia during the 2020 COVID-19 Pandemic through the Example of the Republic of Tatarstan: Discussion on the Change of Open Innovation in the Energy Sector. J. Open Innov. Technol. Mark. Complex. 2020, 6, 60. [CrossRef]

118. Pagliaro, M. Renewable energy in Russia: A critical perspective. Energy Sci. Eng. 2020. [CrossRef]

119. Chebotareva, G. Digital transformation of the energy sector: A case of Russia. E3S Web Conf. 2021, 250, 01001. [CrossRef]

120. Thornbush, M.; Golubchikov, O. Smart energy cities: The evolution of the city-energy-sustainability nexus. Environ. Dev. 2021, 100626. [CrossRef] 
121. Surie, G. Creating the innovation ecosystem for renewable energy via social entrepreneurship: Insights from India. Technol. Forecast. Soc. Chang. 2017, 121, 184-195. [CrossRef]

122. Bauknecht, D.; Funcke, S.; Vogel, M. Is small beautiful? A framework for assessing decentralised electricity systems. Renew. Sustain. Energy Rev. 2020, 118, 109543. [CrossRef]

123. Voskresenskaya, E.; Vorona-Slivinskaya, L.; Achba, L. Development of public services in the energy field in the age of digital economy. E3S Web Conf. 2019, 110, 02031. [CrossRef]

124. Berezin, A.; Sergi, B.S.; Gorodnova, N. Efficiency assessment of public-private partnership (PPP) projects: The case of Russia. Sustainability 2018, 10, 3713. [CrossRef] 